\author{
Piotr Kostyło* \\ Bydgoszcz
}

\title{
Dwa źródła usprawiedliwienia
}

Na początku 2001 roku na łamach „Tygodnika Powszechnego” ukazało się kilka ważnych tekstów dotyczących pojęcia ofiary i daru w teologii i praktyce chrześcijaństwa. Tekstem, który otwierał dyskusję, był artykuł ks. Wacława Hryniewicza pt. Czy Bogu potrzebne sq ofiary? Niezależnie od teologicznego i filozoficznego zorientowania, dyskusja miała także wyraźny walor pedagogiczny. Sposób rozumienia chrześcijaństwa, a zwłaszcza centralnego wydarzenia celebrowanego przez nie, śmierci i zmartwychwstania Jezusa, ma zasadniczy wpływ na to, jak wspólnota naucza swoich członków, jaki obraz religii i świata $\mathrm{w}$ ogóle im przekazuje. Poniższy tekst, będący nawiązaniem do tamtej dyskusji, może być rozumiany także jako pytanie o religię, której się dziś naucza.

Na początku eseju: Czy Bogu potrzebne sq ofiary?, ks. Hryniewicz pyta: „Czy pojęcie ofiary należy do samej istoty religii chrześcijańskiej?” Zaczynam od krótkiego namysłu nad tym pytaniem. Następnie przedstawiam teologiczne uzasadnienie fenomenu, o którym pisze autor, oraz wskazuję możliwą drogę wyjścia teologii z „myślenia w kategoriach ofiary”.

I. Bodajże najbardziej znaną próbą opisania istoty chrześcijaństwa była książka Adolfa von Harnacka Istota chrześcijaństwa, wydana w Lipsku, w 1900 roku. Książka cieszyła się wielkim powodzeniem, za życia autora doczekała się czternastu wydań i została przetłumaczona na tyleż języków.

* Dr hab. Piotr Kostyło, prof. UKW, kierownik Zakładu Filozofii Edukacji w Uniwersytecie Kazimierza Wielkiego w Bydgoszczy. 
Próbując opisać rdzeń Ewangelii, Harnack doszedł do przekonania, że całe przesłanie chrześcijaństwa można by streścić w dwóch prawdach: że Bóg jest Ojcem oraz że dusza ludzka jest czymś tak szlachetnym, iż może się z Nim połączyć i rzeczywiście łączy się. Wszystko inne było dla autora drugorzędne. Ta i podobne próby rodzą pytanie, czy chrześcijaństwo może być traktowane ogólnie i ahistorycznie; czy w ogóle da się z niego wyodrębnić istotę? Z katolickiego punktu widzenia być może byłoby to możliwe, gdyby przyjąć takie rozumienie Objawienia, jakie obowiązywało do ostatniego Soboru. Uznawano wówczas, że Objawienie jest równoznaczne z szeregiem prawd dogmatycznych podawanych do wierzenia katolikom przez autorytet Kościoła. Jeśli nadać by tym prawdom hierarchię, to można by wyodrębnić kilka z nich, które zasługiwałyby na miano ,istoty chrześcijaństwa”. Taki zabieg nie jest jednak możliwy dziś, gdy Objawienie jest utożsamiane nie z szeregiem wypowiedzi, lecz z osobą Jezusa, „który jest zarazem pośrednikiem i pełnią całego objawienia"1. Jak wyodrębnić istotę tego życia? Czy było nią wcielenie? Może nauczanie? Spór z faryzeuszami? Śmierć na krzyżu? Zmartwychwstanie? Nie sposób odpowiedzieć na to pytanie. Albo raczej odpowiedź będzie różna $\mathrm{w}$ zależności od pojedynczego wierzącego, różne aspekty okażą się tu ,istotą”. I nie może być inaczej, skoro samo Objawienie jest konkretne i historyczne. Ma rację zatem Newman, gdy mówi w Eseju o rozwoju doktryny chrześcijańskiej, że „chrystianizm jest jednocześnie dogmatyczny, kultyczny, etyczny; jest ezoteryczny i egzoteryczny; jest pobłażliwy i surowy; jest światłem i ciemnością; jest miłością i bojaźnią"2. Historia życia pojedynczych ludzi, zwłaszcza tych, którzy w dynamiczny sposób odcisnęli swoje piętno na dziejach religii, pokazuje, jak różnie rozumieli oni przesłanie Ewangelii, w jak różnych prawdach dopatrywali się jego istoty. Podobnie, obok tego jednostkowego rozumienia, istnieje także rozumienie powszechne, właściwe dla całych pokoleń; ono także odnosi się do jakiejś istoty, przyjmuje z chrześcijaństwa, najczęściej statycznie, jakiś aspekt, który, przekazywany w nauczaniu, staje się modelem dla kształtowania mentalności wierzących, zyskuje rangę ,istoty chrześcijaństwa”. Właśnie w tym sensie można mówić o istocie chrześcijaństwa, a pojęcie ofiary z pewnością do niej obecnie należy.

${ }^{1}$ Sobór Watykański II, Konstytucja dogmatyczna o Objawieniu Bożym Dei Verbum I, 2.

2 J. H. Newman, O rozwoju doktryny chrześcijańskiej, tłum. J. W. Zielińska, Warszawa 1999, s. 53. 
II. Fenomen, o którym pisze Wacław Hryniewicz, tj. rozumienie przez wielu chrześcijan religii jako przynaglenia do składania ofiar zagniewanemu Bogu, ma swoje teologiczne uzasadnienie. W moim przekonaniu, wynika on z jednostronnego rozumienia nauki o usprawiedliwieniu, która od czasów Reformacji stała się podstawową prawdą kształtującą nauczanie i praktykę chrześcijaństwa. Jako że usprawiedliwienie jest tłumaczone wyłącznie przez doktrynę odkupienia, pierwszą prawdą teologiczną, a często i egzystencjalna, jaką przyswajają sobie chrześcijanie, jest prawda o ich grzeszności. By zrównoważyć tę jednostronną wizję i nadać przesłaniu chrześcijańskiemu właściwe proporcje, należy, moim zdaniem, przemyśleć naukę o usprawiedliwieniu w kontekście doktryny stworzenia. Biblia mówi, że stwarzając człowieka, Bóg widział, że był on bardzo dobry; stworzenie samo w sobie jest już bezwarunkowym usprawiedliwieniem, bardziej pierwotnym od odkupienia. Stworzenie i odkupienie to dwa źródła usprawiedliwienia, które muszą pozostawać wobec siebie we właściwej równowadze. Naruszenie tej równowagi prowadzi wielu chrześcijan do rozumienia i przeżywania swojego życia w kategoriach ofiary.

III. Nie ulega wątpliwości, że idea ofiary jest głęboko zakorzeniona w oficjalnym nauczaniu i praktykach chrześcijaństwa. Głosi się, że Nowe Przymierze zostało ustanowione przez śmierć Jezusa na krzyżu, który ofiarował samego siebie za grzechy świata. Ludzie ofiarują Bogu modlitwę, jałmużnę, cierpienie; księża ofiarują mszę święta, zaś w sakramencie pojednania nakładają na penitentów pokutę, którą także należy ofiarować Bogu. Pojęcie ofiary jest nierozerwalne z językiem chrześcijaństwa. Ten język jest jednak jednostronny i na zewnętrznego obserwatora może działać odpychająco. Tak było w przypadku Nietzschego, według którego „moralizujące chrześcijaństwo stało się religią bierności, ceremonii i nastrojów, odległą od intencji Chrystusa - religią nieszczęśliwych ludzi, pocieszających się przyszłą nagrodą w niebie lub przestraszonych groźbą piekła"3. By odejść od patrzenia na religię w takich kategoriach, ks. Hryniewicz proponuje zastapienie pojęcia ofiary pojęciem daru. Uważam, że to trafna myśl, choć wcielenie jej w życie będzie zadaniem, w dosłownym tego słowa znaczeniu, na całe trzecie tysiąclecie. Zacznijmy jednak od pytania, skąd bierze się pośród wielu chrześcijan przekonanie, że Bóg zaakceptuje ich tylko wtedy, gdy ofiarują $\mathrm{Mu}$ coś znaczącego, z czegoś zrezygnują lub czegoś się zaprą?

3 W. Hryniewicz, Czy Bogu potrzebne sq ofiary?, ,Tygodnik Powszechny” 2 (2001). 
W moim przekonaniu źródeł tej postawy należy szukać w nauce o usprawiedliwieniu, tak jak jest ona rozumiana od czasów Reformacji. Usprawiedliwienie stało się podstawowym pojęciem teologicznym $\mathrm{w}$ dobie sporu Lutra z papiestwem, wcześniej było niemal nieznane, a na pewno nikt nie przedstawiał go w tak bezkompromisowy sposób. W powszechnym mniemaniu wystapienie Lutra łączy się z jego sprzeciwem wobec sprzedawania odpustów. Ten protest dojrzewał w nim jednak długo i stały za nim głębokie egzystencjalne i teologiczne racje. Przez wiele lat Luter był pochłonięty pytaniem, w jaki sposób człowiek, pogrążony w grzechu i niezdolny do czynienia dobra własnymi siłami, może być akceptowany przez Boga, może zyskać usprawiedliwienie. Wydana w Wittemberdze w 1549 roku Historia życia i czynów najczcigodniejszego doktora Martina Luthra, wiernie opisana przez Filipa Melanchtona, opisuje, jak Luter doszedł do rozwiązania tego dylematu:

[...] mniej więcej w tym czasie znalazł on umocnienie w słowach pewnego sędziwego człowieka w Kolegium Augustianów w Erfurcie. Gdy [Luter] wyjawił mu konflikty swojego ducha, [człowiek ów] otworzył jego umysł na nowe widzenie kwestii wiary. [...] wskazał mu ten artykuł Credo, w którym mówi się: „wierzę w grzechów odpuszczenie" i który powinien być interpretowany w następujący sposób: „Konieczne jest wierzyć nie tylko w sensie ogólnym, iż grzechy są odpuszczone niektórym ludziom, gdyż diabły także wierzą że zostały one odpuszczone Dawidowi lub w szczególności Piotrowi, lecz że nakazem Boga jest, by każdy pojedynczy człowiek uświadomił sobie polecenie odpuszczenia grzechów [właśnie] jemu”.

W dalszej części książki Melanchton pisze, że tym, co utwierdzało Lutra w nabytym przekonaniu, był „wydźwięk pism Apostoła Pawła, który jednolicie wyraża doktrynę, że jesteśmy usprawiedliwieni przez wiarę"; a jego codzienna modlitwa sprawiła, że „stopniowo coraz jaśniejsze światło jaśniało nad jego droga"4. Teologicznym problemem o najwyższej wadze było dla Lutra rozwiązanie napięcia między upadłym człowiekiem a zagniewanym Bogiem. Jeśli sprawiedliwość byłaby jednym z atrybutów Boga, On zaś sądziłby nas z zewnątrz, to nikt nie mógłby zostać usprawiedliwiony. Lecz oto Bóg sam jest sprawiedliwością; i jako że jest On także źródłem naszego życia, Jego sprawiedliwość usprawiedliwia nas. Grzeszny człowiek powi-

4 Tłum. moje za tekstem internetowym: www.iclnet.org/pub/resources/text/wittenberg/ melan/lifea-01.txt (dostęp: 20 września 2014 r.). 
nien ufnie wydać się w ręce Boga i wyznać wiarę w Jezusa, gdyż tylko w ten sposób uzyska usprawiedliwienie.

Rzym nie był przygotowany na podjęcie teologicznego wyzwania Lutra. Problem, tak jak stawiał go niemiecki teolog, był zupełnie nowy, obszar, na którym zaczęła toczyć się dyskusja, był „ziemią nieznaną”. Niemniej należało odpowiedzieć na zagrożenie. Sobór Trydencki potępił nauczanie Lutra o usprawiedliwieniu przez wiarę. Ogólnie mówiąc, w oczach Rzymu było ono zbyt jednostronne; nie brało pod uwagę koniecznego przygotowania do usprawiedliwienia, roli uczynków, różnicy między usprawiedliwieniem a uświęceniem. W jednym punkcie Sobór był wszakże zgodny z Lutrem jako punkt wyjścia przyjął jego antropologię, przekonanie o pierwotnym zepsuciu i upadku człowieka. Rozdział I dekretu o usprawiedliwieniu z 1547 roku zaczyna się tymi słowami:

Najpierw św. Sobór oświadcza, że do dobrego i prawdziwego zrozumienia nauki o usprawiedliwieniu każdy musi uznać i wyznać, że przez grzech Adama wszyscy ludzie, utraciwszy niewinność [por. Rz 5, 12], „stali się nieczyści” [Iz 64, 6] i, jak mówi Apostoł, byli „synami gniewu z natury” [Ef 2, 3], jak to wyjaśnił dekret [Soboru] o grzechu pierworodnym. Do tego stopnia „byli oni niewolnikami grzechu" [Rz 6, 20], pod władzą szatana i śmierci, że nie tylko poganie siłami natury, ale i Żydzi, zachowując literę Prawa Mojżeszowego, nie mogli z niego się wyzwolić lub podźwignąć

Rzym dał sobie narzucić tę mroczną antropologię, uznał jej założenia i stanął do walki z Lutrem na polu, które on sam do tej walki wyznaczył. Człowiek pozostający pod władzą szatana i śmierci, skażony grzechem i wydany na pastwę zepsucia, potrzebuje usprawiedliwienia, przyznawał Sobór, lecz osiaga je inaczej niż chciał tego Luter. Diagnoza co do pierwotnego stanu człowieka była podobna, różnica tkwiła w środkach zaradczych. Spór nie toczył się o to, dlaczego usprawiedliwienie jest potrzebne, lecz o to, jak się do niego dochodzi. By zdać sobie sprawę z zasięgu tej antropologii, wsłuchajmy się jeszcze w słowa Johna Henry'ego Newmana, który w latach 30 . XIX wieku tak pisał w jednym ze swoich anglikańskich kazań: ,[...] sam widok naszych win (w miarę, jak nasze oczy otwierają się na nie) odsłania nam tak wielką i tak przytłaczającą nędzę, że jakiś potężny akt, (jeśli można

5 Breviarium Fidei, opr. S. Głowa SJ, I. Bieda SJ, Poznań 1989, s. 314. 
tak to nazwać) ze strony Boga był konieczny, by zrównoważyć oznaki Jego gniewu, które nas otaczają"6.

IV. Tym potężnym aktem stała się ofiara Jezusa, który wydał się za nasze grzechy i umarł na krzyżu. Dzięki tej ofierze jesteśmy usprawiedliwieni, ona wykupiła nas z niewoli śmierci. Od tego momentu o usprawiedliwieniu mówiono wyłącznie w kontekście doktryny odkupienia. Punktem wyjścia była grzeszność człowieka i konieczność jego odkupienia. Nawiązywano tu do wielu starożytnych teorii, spośród których najskrajniejszą była utrzymywana przez niektórych Ojców Kościoła teoria okupu. Mówiła ona, że Jezus musiał zapłacić diabłu okup ze swojego życia, by wykupić ludzi z niewoli grzechu. Najczęściej przywoływano jednak XI-wieczną teorię św. Anzelma (wciąż obecną w aktualnym Katechizmie, zob. numery 615 i 616). Misję Jezusa wyjaśniano w niej przede wszystkim w kategoriach zadośćuczynienia (satisfactio). W myśl tej teorii grzech człowieka spowodował nieskończoną obrazę Boga; ta obraza wymagała nieskończonego zadośćuczynienia, do którego człowiek, jako byt zawdzięczający wszystko Bogu, nie był zdolny; dopiero nieskończona wartość życia Jezusa, Boga-Człowieka, złożonego w ofierze na krzyżu, mogła uśmierzyć Boży gniew. W tej teorii życie Jezusa jest skrajnie podporządkowane Jego śmierci, to ona stanowi centralny punkt objawienia, od niej zależy nasze odkupienie i usprawiedliwienie, ona zadośćuczyniła Bogu za grzech człowieka. Życie Jezusa, z całym jego bogactwem i mądrością, jest zaledwie preludium do aktu spełnionego na Kalwarii. Już ten brak równowagi między życiem i śmiercią jest rzeczą wątpliwą. Istnieje jednak w teorii św. Anzelma trudność o wiele poważniejsza - nie ma ona charakteru biblijnego. Ani Stary, ani Nowy Testament nie znają podobnego pojęcia zadośćuczynienia. Bóg Izraela jest Bogiem Przymierza, trwającym wiernie przy swoim ludzie. Bóg Ewangelii jest miłosiernym Ojcem, który daruje długi, jakiekolwiek by one nie były.

Termin satisfactio pochodzi z prawa rzymskiego i oznacza spłacenie długu wierzycielowi, uczynienie zadość jego roszczeniom. Dłużnik był zobowiązany do tego przez prawo, i jeśli tego nie uczynił, narażał się na postępowanie sądowe, wyrok i egzekucję. Przeniesienie konstrukcji stosunku prawnego na grunt teologii nadało mu charakter absolutny; Bóg jako wierzyciel posiadał absolutną władzę nad grzesznym człowiekiem, zagrożenie zaś, przed którym stawał taki dłużnik, nie spłacając ciążącego na nim zobowiązania, było niewspółmierne z zagrożeniem przewidzianym przez pra-

\footnotetext{
${ }^{6}$ J. H. Newman, Kazania uniwersyteckie, thum. P. Kostyło, Kraków 2000, s. 124.
} 
wo rzymskie; tam mógł się bronić, argumentować, i co najwyżej zostać za długi sprzedany w niewolę lub wtrącony do więzienia, tu nie miał niczego na swoją obronę, a jego niewypłacalność narażała go na wieczne potępienie w piekle. Groźba potępienia jest zresztą nieodłącznym elementem teorii zadośćuczynienia. Jest ona też obecna w doktrynie odkupienia. Samo słowo „odkupienie" także niesie ze sobą wizję zaciągniętego zobowiązania, długu, jaki należy spłacić, ofiarując ustaloną z góry cenę. W tym sensie człowiek w swoich relacjach z Bogiem pozostaje zawsze „na minusie”, niepewny, czy ofiara, jaką złożył, jest wystarczająca, czy cierpienie, jakie znosi, czyni zadość jego Stwórcy. Relacje między człowiekiem a Bogiem można by nazwać „duchową buchalterią”, odkreślaniem tego, co już zostało spłacone, i przypominaniem o istniejących wciąż zobowiązaniach. Akceptacja ze strony tak rozumianego Boga zawsze pozostaje warunkowa i niepewna; usprawiedliwienie może być człowiekowi ofiarowane, ale i może być mu odmówione. Taka jest nieubłagana logika prawa, właściwa dla tego źródła usprawiedliwienia - doktryny odkupienia. W świadomości wielu chrześcijan jest to, niestety, jedyna logika.

V. Otóż oprócz tego źródła usprawiedliwienia istnieje także inne, bardziej pierwotne, wybijające $\mathrm{z}$ samych głębin Bożego życia, nadające strukturę i sens całej rzeczywistości. Jest to źródło, które bierze swój początek nie w ogrodzie Eden, po upadku i wygnaniu stamtąd pierwszych rodziców, ale nad wodami, nad którymi unosił się Duch Boży, Bóg zaś „nazwał światłość dniem, a ciemność nazwał nocą" ( $\operatorname{Rdz} 1,5)$ i wszystko, co istnieje, powołał do życia ${ }^{7}$. Teologicznym wyrazem tego źródła jest doktryna stworzenia. Biblia przedstawia akt stworzenia jako pracę Boga, który czyni, oddziela i mówi; Jego słowo ma moc stwarzania, oznajmia i dokonuje tego, co oznajmia jednocześnie. W odróżnieniu od ościennych mitologii, Bóg Izraela jest przedstawiony jako jedyny i absolutny Pan stworzenia, nieuwikłany w walkę z siłami ciemności, suwerenny i niezagrożony przez nikogo w dziele stworzenia. Nawet gdy na kartach Biblii pojawiają się mitologiczne potwory, jak na przykład Lewiatan wymieniany w szeregu psalmów, to nie po to, by toczyć z Bogiem bój o panowanie nad światem, lecz by swoją podległością podkreślać Bożą potęgę. Zadziwiające jest, że monstra budzące powszechne przerażenie bywają przedstawiane jako Boże stworzenia i są traktowane przez Stwórcę z łagodnością i wyrozumiałościa, będąc dla Niego źródłem radości, niemal zabawy. „Oto morze wielkie, długie i szerokie / a w nim jest

7 Wszystkie cytaty z Pisma Świętego za: Biblia Tysiaclecia, Poznań 2002. 
bez liku żyjątek / i zwierząt wielkich i małych. / Tamtędy wędrują okręty, / i Lewiatan, którego stworzyłeś na to, / by w nim igrał" (Ps 104, 25-26). Doktryna stworzenia nie pozostawia miejsca na manicheizm, Bóg jest jedynym źródłem życia, a wszystko, co z Niego bierze początek, jest dobre.

Ukoronowaniem dzieła stworzenia jest człowiek. „Stworzył więc Bóg człowieka na swój obraz, na obraz Boży go stworzył: stworzył mężczyznę i niewiastę" (Rdz 1,27). W odróżnieniu od filozofii greckiej stworzenie człowieka nie łączy się z ani z jego upadkiem, ani z degradacją. W filozoficznych systemach emanacyjnych dusze pojawiały się na ziemi, spadając ze świata idealnego w świat realny, i podlegały degradacji, przyjmując cielesność. Biblia jest jak najdalsza od takiego przedstawiania początków życia. Człowiek jest pierwszym dziełem stworzenia, gdyż wszystko inne zostało stworzone ze względu na niego; został postawiony w centrum jako punkt odniesienia dla pozostałych stworzeń. Święty Ireneusz mówi, że Bóg, stwarzając człowieka, widział już swojego Syna! Ten sam autor tłumaczy też, na czym polega stworzenie na „obraz i podobieństwo Boga”. Mówi, że od momentu stworzenia człowiek, niosący w sobie pierwotny obraz Boga, wchodzi w dynamikę kształtowania w sobie podobieństwa do zmartwychwstałego Chrystusa, będącego obrazem ludzkości u jej kresu. Błogosławiąc człowieka, Bóg przekazuje mu jednocześnie władzę nad ziemią: „Bądźcie płodni i rozmnażajcie się, abyście zaludnili ziemię i uczynili ją sobie poddaną" (Rdz 1, 28). Bóg nie stwarza człowieka ,pod warunkiem”, lecz bezwarunkowo, dając mu wolność i czyniąc go panem stworzenia. Ten pierwotny dar wolności jest powołaniem człowieka do miłości i odpowiedzialności; nie może być zresztą inaczej, skoro Bóg jako pierwszy traktuje człowieka w taki właśnie sposób.

Jeśli spojrzymy na usprawiedliwienie z tego punktu widzenia, to okaże się, że mamy tu do czynienia z zupełnie inną antropologią niż w doktrynie odkupienia. Choć zależność człowieka od Boga jest tu nieporównywalnie większa - w Nim bowiem żyjemy, poruszamy się i jesteśmy - to jednak nie ma ona charakteru roszczeniowego; Bóg niczego nie żąda, z niczego nie rozlicza, po prostu pozwala być. Punktem wyjścia nie jest tu zepsucie, grzeszność czy upadek człowieka, lecz jego dobro, wielkość i kruchość zarazem (człowiek otrzymał życie od Boga, lecz został ulepiony z prochu ziemi!). Z tej kruchości Bóg nie czyni jednak człowiekowi zarzutu, pochyla się nad nią z troską i miłością, zabiega o życie, chroni je: „Nie złamie trzciny nadłamanej, / nie zgasi knotka o nikłym płomyku" (Iz 42, 3). Stworzenie nie niesie też ze sobą cierpienia Boga; przeciwnie, jest źródłem Jego głębokiej satysfakcji. Na próżno by w nim szukać elementów merkantylnych, wymiany, dawania czegoś za coś. Dar życia zostaje przekazany nie ze względu na 
zasługi człowieka, lecz ze względu na wolną decyzję Boga. Bóg dzieli się życiem z człowiekiem, przekazuje mu „tchnienie życia”. Tę tajemnicę wysławia psalmista, gdy mówi: „Ty bowiem utworzyłeś moje nerki, / Ty utkałeś mnie w łonie mej matki" (Ps 139, 13), a także Hiob, który z głębin swojej udręki wyznaje: „Odziałeś mnie skórą i ciałem / i spiąłeś żyłami i kośćmi” (Hi 10,11). Więź między Bogiem a człowiekiem jest mocniejsza niż więź między matką a dzieckiem. „Czyż może niewiasta zapomnieć o swym niemowlęciu, / ta, która kocha syna swego łona? / A nawet, gdyby ona zapomniała, / Ja nie zapomnę o tobie" (Iz 49, 15). Trudno sobie wyobrazić głębszy wyraz bezwarunkowej akceptacji człowieka, pełniejsze i bardziej pierwotne usprawiedliwienie. Stworzenie wyprzedza odkupienie nie tylko w czasie, ale i w randze Bożego daru. Ono jest pierwszym źródłem usprawiedliwienia, warunkiem, by historia zbawienia w ogóle mogła się rozpocząć. Niestety, to źródło zostało przez chrześcijan zapomniane.

VI. O ile doktryna odkupienia w naturalny sposób odwołuje się do pojęcia ofiary, o tyle doktryna stworzenia bliższa jest pojęcia daru. Mroczna i pesymistyczna wizja człowieka towarzysząca pierwszej jest równoważona przez wdzięczność za życie i radość tworzenia obecne w drugiej. Tu i tam człowiek jest bezradny, lecz jakże różna to bezradność! W pierwszym wypadku to bezradność grzesznika, który zniszczył swoje, a często i cudze życie, i drży $\mathrm{z}$ niepewności w oczekiwaniu na odkupienie. W drugim wypadku, to bezradność dziecka, które wyszło z rąk swojego Stwórcy i zdoła rozwinąć się w pełni tylko wówczas, gdy znajdzie w życiu klimat miłości i odpowiedzialności. Tu człowiek boryka się z bolesną świadomością, że akceptacja Boga jest zawsze warunkowa, i by zasłużyć sobie na Bożą przychylność, należy złożyć coś w ofierze; tam staje wobec bezwarunkowego daru życia, które należy podjąć i rozwijać dla dobra swojego i innych ludzi; tu, kontemplując swoje grzechy, przepełniony jest niechęcią czy wręcz odrazą do samego siebie; tam, świadomy wagi życia, zachwyca się sobą jako Bożym stworzeniem; tu usprawiedliwieniem jest w jego oczach to, co się dla Boga uczyniło; tam samo jego istnienie jest już usprawiedliwieniem.

Niestety w mentalności wielu chrześcijan obecne jest tylko „tu”, o „tam” wspomina się jedynie mimochodem jako o utraconym raju, do którego nie ma już powrotu. Nauka o grzechu pierworodnym sprowadziła stworzenie do rangi odległego mitu, do poziomu czasu zaprzeszłego, z którego pozostał jedynie barwny przekaz Biblii. Anioł, który z mieczem w ręku strzeże wejścia do Ogrodu Eden, zdaje się także strzec drogi do pierwotnego usprawiedliwienia, darowanego nam przez Boga wraz z życiem. Potężny akt Boga, 
stwarzający kogoś nieporównywalnie ważniejszego od nieba i ziemi, lądów i mórz, zostaje sprowadzony do zewnętrznej wobec nas opowieści, podziwianej co najwyżej na kościelnych witrażach. Teraz, po grzechu pierwszych rodziców, stworzenie zdaje się pozostawać poza naszym zasięgiem, i nawet jeśli w nie wierzymy, to tylko w sensie ogólnym, uważając Boga za źródło wszystkiego, co istnieje, lecz nie widząc, że jest On bezpośrednim źródłem mojego osobistego istnienia. Niedocenianie rangi stworzenia stawia jednak pod znakiem zapytania potęgę Stwórcy. Życie zostaje oddzielone od swojego Źródła i dryfuje w bezradnym poszukiwaniu pełnego usprawiedliwienia. Jak ubogie jest to pojęcie stworzenia! O ileż bogatszą wizję przedstawia Henri Bergson w Ewolucji twórczej, gdy opisując stworzenie mówi: „Bóg, tak określony, nie ma w sobie nic [ostatecznie] zakończonego: jest nieustannym życiem, działaniem, wolnością. Stworzenie, tak pojęte, nie jest tajemnicą; doświadczamy Go w sobie, skoro tylko działamy w sposób wolny"s.

Parafrazując słowa, które Luter usłyszał od sędziwego człowieka w Erfurcie, powiedzmy, że konieczne jest wierzyć nie tylko w sensie ogólnym, iż świat został stworzony, lecz że nakazem Boga jest, by każdy pojedynczy człowiek uświadomił sobie, iż Bóg stworzył właśnie jego. Stworzył, a więc usprawiedliwił, przyjął jako dziecko, jako przybraną córkę i syna. Zapoznanie tego pierwotnego źródła usprawiedliwienia, skupienie się wyłącznie na doktrynie odkupienia, rozumianej jako ofiarowanie Jezusa za grzechy świata, prowadzi z konieczności do zredukowania nauki o usprawiedliwieniu do poziomu warunkowego aktu Boga, który, owszem, akceptuje człowieka, lecz dopiero wówczas, gdy ten albo wzbudzi w sobie wystarczającą ufność i wyzna wiarę w Jezusa, albo spełni warunki określone przez Kościół dla dobrej i ważnej spowiedzi, i otrzyma sakramentalne rozgrzeszenie. Zanim pierwszy lub drugi warunek nie zostanie spełniony, Bóg pozostaje zagniewanym Sędzią, żądającym spłacenia zaciągniętego przez grzech długu i grożącym wiecznym potępieniem tym, którzy spłacić go nie chcą lub nie potrafią. Problem $\mathrm{z}$ takim widzeniem usprawiedliwienia polega na tym, że w przypadku protestantyzmu nawet najgłębszy akt wiary nie zmienia życia człowieka od razu, wiele wad i grzechów ciągnie się za nim latami, i trudno dać sobie radę $\mathrm{z}$ napięciem między szczerze wyznawaną wiarą a ciagłą nieadekwatnością swojego życia; w przypadku katolicyzmu natomiast, naturalne poczucie winy wynikające z popełnionego zła bywa wzmacniane przez skru-

8 Tłum. moje na podstawie: Henri Bergson, Oeuvres, Paris 1991, s. 706. W tłumaczeniu F. Znanieckiego wątpliwości budzi przekład librement przez „dowolnie”. Patrz: Henryk Bergson, Ewolucja twórcza, Warszawa 1957, s. 220. 
puły towarzyszące spowiedzi, w której aspekt prawny często przeważa nad aspektem duchowym, a dbałość o jej formalną ważność zaciemnia sens jej ustanowienia. Tak długo, jak doktryna odkupienia nie będzie zrównoważona przez doktrynę stworzenia, chrześcijanie będą skłonni do upatrywania istoty swojej religii w pojęciu ofiary, gdyż najpierw oni sami są przedstawiani jako ofiary grzechu, następnie śmierć Jezusa jest przedstawiana jako ofiara za ich grzechy, i wreszcie ofiarowywanie siebie jest przedstawiane jako najlepsza droga naśladowania Jezusa. Tej logiki pozwala uniknąć doktryna stworzenia. Przypomina ona, że początkiem historii zbawienia nie jest grzech człowieka, lecz stwórczy akt Boga. Ten akt jest zarazem powołaniem człowieka do życia i usprawiedliwieniem go, w gruncie rzeczy samo istnienie człowieka jest już fundamentalnym usprawiedliwieniem. Bóg daje życie człowiekowi w sposób bezwarunkowy, niczego nie żąda w zamian, nie ma tu mowy o spłacaniu zobowiązań i wyrównywaniu rachunków. Nawet złe serce człowieka nie potrafi odmienić tej pierwotnej przychylności, gdyż „On sprawia, że słońce Jego wschodzi nad złymi i nad dobrymi, i On zsyła deszcz na sprawiedliwych i niesprawiedliwych" (Mt 5, 45). Dopiero usprawiedliwienie rozumiane w kontekście stworzenia pozwala zrównoważyć negatywną antropologię przejętą przez nowożytne chrześcijaństwo od Lutra i uniknąć języka ofiary.

VII. Nadanie właściwych proporcji stworzeniu i odkupieniu w kontekście nauki o usprawiedliwieniu stawia szereg wyzwań przed teologią, ale i daje jej dużo nadziei. Na początku wymaga, by w nowym świetle zobaczyć, kim jest Bóg. Trudno sobie wyobrazić, by ten sam Bóg najpierw stwarzał człowieka na „swój obraz i podobieństwo”, i potwierdzał, że jest on bardzo dobry, a następnie groził swojemu stworzeniu unicestwieniem; najpierw w bezwarunkowy sposób przekazywał dar życia, a następnie zgadzał się na potępienie tego daru. Argumentowanie, że to grzech człowieka wzbudza Boży gniew i doprowadza do zmiany Jego nastawienia, nie jest przekonujące, przede wszystkim dlatego, że uzależnia pierwotny zamysł Stwórcy od wyborów człowieka i podaje w wątpliwość pełnię Bożej akceptacji względem stworzenia. Jeśli istotnie Bóg reagowałby złością na grzech człowieka, to byłby On bardziej podobny do bogów greckiego panteonu niż do Boga Biblii.

Przesunięcie akcentów, o których mówimy, byłoby też z wielkim pożytkiem dla ekumenizmu. $Z$ teologicznego punktu widzenia rozdarcie zachodniego chrześcijaństwa dokonało się wskutek zasadniczej niezgody co do środków zaradczych, jakie należy stosować, by człowiek mógł powstać 
z upadku grzechu i zyskać usprawiedliwienie. Tymczasem namysł nad stworzeniem pozwoliłby dostrzec, że problemem są nie tyle środki, co pierwotna diagnoza stanu człowieka. Czy istotnie jest on tak beznadziejny, jak postulował Luter? Czy Rzym nie popełnił błędu przyjmując ten postulat? Antropologia biblijna, nie dogmatyka, wydaje się zatem właściwszym miejscem spotkania katolicyzmu i protestantyzmu.

Oczywiście takie przesunięcie akcentów musi budzić pytanie o chrystologię. Czy podkreślanie rangi stworzenia jako obszaru bezwarunkowego usprawiedliwienia człowieka nie redukuje odkupienia do poziomu opcjonalnego aktu Boga, który, niezależnie od wcielenia, śmierci i zmartwychwstania Chrystusa, i tak uratowałby ludzkość? Innymi słowy, czy stworzenie nie zawiera już w sobie implikatywnie odkupienia? Dotykamy tu sedna pytania ks. Hryniewicza: „Czy Bogu potrzebne są ofiary?” Na misję Jezusa można bowiem patrzeć dwojako: albo jako na wypełnienie z góry powziętego planu, zgodnie z którym Syn zostaje posłany przez Ojca na ziemię, by odkupić ludzi, oddając za nich swoje życie: albo jako na dar Ojca, który przez swojego Syna chciał objawić światu miłość, która jest wewnętrznym życiem Trójcy Świętej. W pierwszym wypadku odkupienie byłoby wypełnieniem zaplanowanej misji, w której centralnym punktem była śmierć Jezusa, także, jeśli można tak powiedzieć, zaplanowana; w drugim wypadku, byłoby ono objawieniem Bożego życia między nami, w którym centralnym punktem była miłość doskonała, wierna aż do śmierci, pomimo śmierci i poza śmierć. W pierwszym wypadku misja Jezusa uzależniona byłaby od grzechu człowieka; w drugim byłaby raczej wypełnieniem tej miłości, która stała już u początków stworzenia. Otóż, jeśliby przyjąć pierwsze podejście, to, istotnie, usprawiedliwienie przez stworzenie nie mieści się w obrębie takiej chrystologii. Inaczej rzecz się ma z drugim podejściem. Tu misja Jezusa nie stałaby w sprzeczności z pierwotnym usprawiedliwieniem, przeciwnie, potwierdzałaby je. W tej chrystologii centralne jest bowiem nowe stworzenie, wolne od lęku i wdzięczne za przedziwny dar życia. ,Jesteśmy bowiem Jego dziełem, stworzeni w Chrystusie Jezusie dla dobrych czynów, które nam Bóg z góry przygotował, abyśmy je pełnili" $(\mathrm{Ef} 2,10)$.

Trzeba tu jeszcze wspomnieć o dwóch doktrynach, które w świetle tego, co zostało powiedziane, wymagałyby głębokiego teologicznego namysłu. Myślę tu o doktrynie Trójcy Świętej oraz, przede wszystkim, o doktrynie grzechu pierworodnego. Uznanie istnienia dwóch źródeł usprawiedliwienia byłoby mocnym impulsem do sformułowania nowych pytań w obu obszarach. Mam nadzieję, że nadejdzie czas, gdy te pytania zostaną postawione. 
Zakończmy innym pytaniem: Czy może być tak, że w nauce o usprawiedliwieniu logika prawa rzymskiego przeważa nad logiką Biblii? Od ponad czterech wieków tak właśnie jest; i tak długo jak zachwiane proporcje nie zostaną przywrócone, człowieka nawiedzać będzie myśl, że usprawiedliwienie może być mu odmówione. To, że nauka o usprawiedliwieniu wymaga głębokiego namysłu, nie jest zresztą moim odkryciem. „Trzeba jednak przyznać, że tak w życiu Kościoła, jak w życiu Wspólnot luterańskich doktryna ta nie jest ani szczególnie obecna, ani żywa. To zadziwiające, że nauka o usprawiedliwieniu, uznawana za kryterium wiary, kryterium życia Kościoła, jest prawie nieobecna w zbiorowej świadomości, nawet luteranów. Przemyślenie jej i zaktualizowanie stanowi wspólne wyzwanie dla katolików i dla protestantów".

\section{Two Sources of Justification (Summary)}

The article concerns one of the key doctrines of Christianity - the one of justification which, in the modern times, has become a theological reason for the division of Western Christianity. The author points out that relating the doctrine of justification exclusively to the doctrine of redemption has entailed a number of undesired consequences, e.g. treating life like a sacrifice by many Christians. Showing justification in the light of the doctrine of creation would allow to abandon that pessimistic vision and to turn to treating life like a gift. It would also have a positive impact on religious education.

Keywords: Justification, redemption, creation, sacrifice, gift

\section{Dwa źródła usprawiedliwienia (Streszczenie)}

Artykuł dotyczy jednej z kluczowych doktryn chrześcijaństwa - usprawiedliwienia, która w okresie nowożytnym stało się teologicznym powodem podziału Kościoła na Zachodzie. Autor wskazuje, że odniesienie doktryny usprawiedliwienia wyłącznie do doktryny odkupienia pociągnęło za sobą szereg niepożądanych kon-

9 Dialog jest koniecznościq. Kardynat Joseph Ratzinger odpowiada na pytania „Znaku”, „Znak” 11 (1999), s. 7-8. 
sekwencji, między innymi traktowanie życia przez wielu chrześcijan jako ofiarę. Ukazanie usprawiedliwienia w świetle doktryny stworzenia pozwoliłoby odejść od tej pesymistycznej wizji i zwrócić się w stronę traktowania życia jako daru. Miałoby to z pewnością bardzo pozytywny wpływ także na wychowanie religijne.

Słowa kluczowe: usprawiedliwienie, odkupienie, stworzenie, ofiara, dar 